\title{
Response to Intervention or Responsive Instruction? Challenges and Possibilities of Response to Intervention for Adolescent Literacy
}

William G. Brozo

I t is difficult to deny that many U.S. middle and high school students are in need of special literacy supports.

- Approximately two thirds of 8th- and 12th-grade students read at less than the "proficient" level on the National Assessment of Educational Progress (Rampey, Dion, \& Donahue, 2009).

- Nearly $32 \%$ of high school graduates are not adequately prepared for college-level English composition courses (ACT, 2005).

- Approximately $40 \%$ of high school graduates lack the literacy skills employers seek (National Education Summit on High Schools, 2005).

- About 1.2 million students drop out annually, and their literacy skills are lower than most industrialized nations (Laird, DeBell, Kienzl, \& Chapman, 2007; Organisation for Economic Co-Operation and Development, 2001).

In no small way, these and other indicators of declining literacy achievement have shifted national attention toward struggling and striving adolescent readers. More than ever, secondary schools are under enormous pressure to find ways of improving performance for these youth. Then came reauthorization of the Individuals With Disabilities Education Act (IDEA; U.S. Department of Education, 2004), which contains regulations for a Response to Intervention (RTI) approach for identifying students who may be eligible for specific learning disability services. And almost overnight, countless secondary schools across the United States that previously had no structured literacy programs have been adopting the RTI model.

RTI commonly involves three tiers of support. The first represents instruction and services available to all students, generally provided at the classroom level. The second targets short-term instruction for small groups of students who need extra help. The third tier represents the most intensive level of instruction and is usually provided in a one-to-one context. Students receive 


\section{Looking at}

secondary reading

only through

a disabilities

lens...reinforces

stereotypes about

the nature of

reading for students

in middle and high

school. different tiers of support depending on how they respond to interventions at any one level.

Looking at secondary reading only through a disabilities lens, however, reinforces stereotypes about the nature of reading for students in middle and high school (Alvermann \& Rush, 2004). With nearly a hundred years of scholarship to inform us (Mraz, Rickelman, \& Vacca, 2009), we know that secondary students who struggle to make meaning from the complex prose they're confronted with daily aren't necessarily remedial readers.

The typical demands of a secondary school curriculum require students to possess sophisticated language tools to explore information and concepts in content area subjects, such as history, mathematics, science, and literature (Borasi \& Siegel, 2000; Crawford, Kelly, \& Brown, 2000; Hinchman \& Zalewski, 1996). Thus, all adolescents are challenged to one degree or another by increasingly difficult school-based texts as well as greater content learning expectations (Biancarosa \& Snow, 2006; Brozo \& Simpson, 2007).

Although research around RTI at the elementary level has been ongoing, studies into the best ways of implementing the process for secondary students are scant (Duffy, n.d.). Thus, in the absence of research and documented successes at the secondary level, it falls to middle and high schools to devise their own approaches to implementing responsive tiered interventions for adolescent literacy (Shanklin, 2008). This is ironic because the provision in IDEA stresses the need for RTI programs to be supported by interventions that are based on scientific research (U.S. Department of Education, 2004). Nonetheless, in spite of the lack of scientific evidence for secondary level RTI, numerous middle and high schools across the United States are moving ahead with three-tier approaches to instructional intervention.

Given this state of affairs, I propose that three essential questions should be asked by secondary teachers, administrators, and literacy professionals when considering whether and how to structure RTI-like programs for adolescents.

\section{Is RTI a Feasible Structure for Secondary Literacy?}

As interest in the utility of RTI at the secondary level grows (Duffy, n.d.), it offers the potential to bring about a review of an entire school's model for adolescent literacy, including its services, interventions, and terminology (Shanklin, 2008). The International Reading Association's Commission on RTI (2009), however, cautions against the proclivity of some districts and schools to institute RTI at the secondary level based on primary/elementary approaches. There are several reasons why the commission's warning is valid.

First, although implementation of RTI-like tiered interventions for the early grades has proven possible (Fuchs \& Fuchs, 2006), there is little research currently available on the use of RTI in the upper grades (Cobb, Sample, Alwell, \& Johns, 2005). This significant lack of research evidence alone should be enough to give pause to those secondary teachers and administrators who demand a scientific basis for all elements of a reading program.

Second, the structure and culture of secondary schools (O’Brien, Stewart, \& Moje, 1995) limits the feasibility of RTI as a comprehensive model of reading. In elementary-level, self-contained classrooms, a teacher may have a single group of students the entire day. Providing whole-class, small-group, and individualized reading instruction is not only possible within that setting but also an expectation. Additionally, weaving the language arts into all aspects of the curriculum is readily achieved in typical early grades' classrooms. In contrast, consider someone like a 10th-grade U.S. history teacher working in a block schedule. He sees a group of students every other day, is under strong pressure to cover the content standards and gradelevel expectancies of U.S. history, and may only be superficially knowledgeable of and less experienced in content literacy strategies. Furthermore, based on my experience, this typical high school teacher is likely to see himself first and foremost as a specialist in history content, which he imparts through whole-group lessons, and provides help to individual students who seek it over that same content. Students who need extra literacy and learning supports are referred to other 
high school specialists, such as the reading and special education teacher.

A third and rather ubiquitous challenge to RTI programs in U.S. middle and high schools is scheduling. If space cannot be found or created within the school day for deserving students to receive appropriate instructional supports, then the foundation upon which RTI rests-that is, the flexibility to create tiered interventional contexts for students depending upon their responses to the instruction provided within each-is undermined.

\section{Is RTI the Most Effective Model for a Comprehensive Secondary Literacy Program?}

As we know, to be a successful reader for academic purposes in middle and high school, adolescents need much more than skill in decoding words or the ability to read smoothly and quickly. They must also be knowledgeable of and have control over a range of sophisticated literacy strategies. Yet the emphasis on "scientific" evidence automatically limits the scope of a school-based adolescent literacy program. And the progress-monitoring tools often recommended in the literature as accompaniments to RTI and those in use in schools with which I'm familiar narrow the program's focus even more (Brozo, in press). This is because these monitoring methods tend to emphasize simple, surface-level indicators of reading skill-a vestige of RTI at the primary/elementary gradessuch as oral reading fluency indicated by the number of words correct per minute.

It's important, then, to ask what's missing in RTI when it serves as the framework for a comprehensive adolescent reading program. Because of its cognitive and behavioral orientation, RTI-inspired programs are unlikely to accommodate recent theorizing and scholarship around self-efficacy, youth culture, and new literacies. For instance, a body of evidence (Alvermann, 2002a; Bandura, 1993; Bean, 2000; Pajares, 1996; Phelps \& Hanley-Maxwell, 1997) makes clear that youth are more likely to succeed academically and go on to be successful in adulthood when they see themselves as able and authorized members of learning communities (Cook-Sather, 2002; Edwards, 2001; Sturtevant et al., 2006). Yet many adolescents who possess talent, energy, and intelligence find themselves in school settings where these abilities may go untapped (Hinchman, Alvermann, Boyd, Brozo, \& Vacca, 2004). The failure to align school curricula with students' interests and outside-of-school competencies is thought to be behind the general erosion of engagement in reading and learning experienced by many youth as they make the transition from elementary to secondary school (Anderman, Maehr, \& Midgley, 1999; Eccles et al., 1993; McPhail, Pierson, Freeman, Goodman, \& Ayappa, 2000). It's possible, then, that RTI-based reading programs may do little to improve student motivation, especially if the programs' conventional instructional routines fail to address the competency and identity needs of adolescents (Gee, 2001; McCarthey \& Moje, 2002).

RTI-inspired secondary reading programs may also leave little room for youth literacies. Only within the past two decades have researchers begun to focus on the variety of ways youth learn literacies, the interconnecting contexts in which literacies are learned, and their multiple purposes for engaging literate practices. This scholarship has emphasized the role of multimodal forms of representation and meaning making in the lives of young people (Cope \& Kalantzis, 2000; O'Brien \& Bauer, 2005). Those on the vanguard of new multiliteracies (cf. Street, 2003) argue that "literacy pedagogy must now account for the burgeoning variety of text forms associated with information and multimedia technologies" (New London Group, 1996, p. 60). At the same time that many (Alvermann, 2002b; Goodman, 2003; Kress \& Van Leeuwen, 2001; Love, 2004; Schofield \& Rogers, 2004) are urging secondary schools to make room in language and disciplinary curricula for students' different experiences and outside-of-school discourses expressed through a variety of media, RTI tends to reduce the parameters of what counts as literacy to a few basic, core reading skills and strategies.

\section{Can RTI Provide Responsive Literacy Instruction for All Students?}

Framed as responses to interventions, RTI approaches may perpetuate the myth that only scientifically based instructional strategies will increase reading achievement for students. The idea is that if the interventions 


\section{If content teachers}

fail to offer

responsive literacy

instruction to benefit

every student and

differentiated

assistance for those

in need of extra

help, then the

preventive potential

of RTI is lost. are regarded by proponents as scientifically sound, then students should improve when exposed to them, and if they don't, the problem isn't with the interventions (Kavale, Kauffman, Bachmeier, \& LeFever, 2008). This logic has been challenged on the grounds that it ignores valid but contravening research evidence and limits instructional options that have potential for success (Allington, 2009). For secondary teachers working with youth who bring to their classrooms unparalleled diversity of language, culture, and literacy competencies, limiting instructional options would seem counterintuitive.

What RTI has going for it is the goal of being preventive. This admirable feature, however, introduces the immense challenge of preparing all teachers, like the typical history teacher I referred to earlier, to deal with the wide-ranging and differentiated needs of students. Preventive action in an RTI program should occur primarily in the general education classroom within the so-called Tier I. At the secondary level this means content area classrooms. For those of us well seasoned in school-based, adolescent literacy reform, we know how difficult it is to overcome resistance by middle and high school teachers to incorporate responsive literacy practices into their daily lessons. Thus, RTI's most important first tier is its weakest link at the secondary level. If responsive literacy instruction isn't provided at Tier I, many students who might otherwise be able to succeed without Tier II or III interventions - and avoid the time, attention, and stigma often associated with remedial instructionwill inevitably find themselves in need of intensive supports.

In other words, RTI at the secondary level is only as good as its preventive supports. If content teachers fail to offer responsive literacy instruction to benefit every student and differentiated assistance for those in need of extra help, then the preventive potential of RTI is lost. When this happens, RTI at the secondary level becomes little more than a delivery system for remedial reading and, as such, cannot be regarded as a comprehensive program that supports the literacy competencies of all youth.

\section{References}

ACT. (2005). Average national ACT score unchanged in 2005: Students graduate from high school ready or not. Retrieved June 11, 2009, from www.act.org/news/releases/2005/8-17-05.html

Allington, R.L. (2009). What really matters in response to interventions: Research-based designs. Boston: Allyn \& Bacon.

Alvermann, D.E. (2002a). Effective literacy instruction for adolescents. Journal of Literacy Research, 34(2), 189-208. doi:10.1207/ s15548430j1r3402_4

Alvermann, D.E. (2002b). Adolescents and literacies in a digital world. New York: Peter Lang.

Alvermann, D.E., \& Rush, L.S. (2004). Literacy intervention programs at the middle and high school levels. In T.L. Jetton \& J.A. Dole (Eds.), Adolescent literacy research and practice (pp. 210-227). New York: Guilford.

Anderman, E.M., Maehr, M.L., \& Midgley, C. (1999). Declining motivation after the transition to middle school: Schools can make a difference. Journal of Research and Development in Education, 32(3), 131-147.

Bandura, A. (1993). Perceived self-efficacy in cognitive development and functioning. Educational Psychologist, 28(2), 117-148. doi:10.1207/s15326985ep2802_3

Bean, T. (2000). Reading in the content areas: Social constructivist dimensions. In M.L. Kamil, P.D. Pearson, \& R. Barr (Eds.), Handbook of reading research (Vol. 3, pp. 631-644). Mahwah, NJ: Erlbaum.

Biancarosa, C., \& Snow, C.E. (2006). Reading next-A vision for action and research in middle and high school literacy: A report to Carnegie Corporation of New York (2nd ed.). Washington, DC: Alliance for Excellent Education. Retrieved September 17, 2009, from www.all4ed.org/files/ReadingNext.pdf

Borasi, R., \& Siegel, M. (2000). Reading counts: Expanding the role of reading in mathematics classrooms. New York: Teachers College Press.

Brozo, W.G. (in press). Response to intervention for secondary literacy: Meeting the needs of striving adolescent readers. New York: Teachers College Press.

Brozo, W.G., \& Simpson, M.L. (2007). Content literacy for today's adolescents: Honoring diversity and building competence. Upper Saddle River, NJ: Merrill/Prentice Hall.

Cobb, B., Sample, P., Alwell, M., \& Johns, N. (2005). Effective interventions in dropout prevention: A research synthesis. The effects of cognitive-behavioral interventions on dropout prevention for youth with disabilities. Clemson, SC: National Dropout Prevention Center for Students With Disabilities.

Cook-Sather, A. (2002). Authorizing students' perspectives: Toward trust, dialogue, and change in education. Educational Researcher, 31(4), 3-14. doi:10.3102/0013189X031004003

Cope, B., \& Kalantzis, M. (2000). Multiliteracies: Literacy learning and the design of social futures. London: Routledge.

Crawford, T., Kelly, G.J., \& Brown, C. (2000). Ways of knowing beyond facts and laws of science: An ethnographic investigation of student engagement in scientific practices. Journal of Research in Science Teaching, 37(3), 237-258. doi:10.1002/(SICI)10982736(200003)37:3<237::AID-TEA2>3.0.CO;2-6 
Duffy, H. (n.d.). Meeting the needs of significantly struggling learners in high school: A look at approaches to tiered intervention. Washington, DC: American Institutes for Research. Retrieved March 15, 2009, from www.betterhighschools.org/docs/NHSC_ RTIBrief_08-02-07.pdf

Eccles, J.S., Wigfield, A., Midgley, C., Reaman, D., MacIver, D., \& Feldlaufer, H. (1993). Negative effects of traditional middle schools on students motivation. The Elementary School Journal, 93(3), 553-573. doi:10.1086/461740

Edwards, S. (2001). Bridging the gap: Connecting school and community with service learning. English Journal, 90(5), 3944. doi:10.2307/821853

Fuchs, D., \& Fuchs, L.S. (2006). Introduction to response to intervention: What, why, and how valid is it? Reading Research Quarterly, 41(1), 93-98. doi:10.1598/RRQ.41.1.4

Gee, J.P. (2001). Reading as situated language: A sociocognitive perspective. Journal of Adolescent \& Adult Literacy, 44(8), 714-725. doi:10.1598/JAAL.44.8.3

Goodman, S. (2003). Teaching youth media: A critical guide to literacy, video production, and social change. New York: Teachers College Press.

Hinchman, K.A., Alvermann, D.E., Boyd, F.B., Brozo, W.G., \& Vacca, R.T. (2004). Supporting older students' in- and outof-school literacies. Journal of Adolescent \& Adult Literacy, 47(4), 304-310.

Hinchman, K.A., \& Zalewski, P. (1996). Reading for success in a tenth-grade global-studies class: A qualitative study. Journal of Literacy Research, 28(1), 91-106.

International Reading Association Commission on RTI. (2009). Working draft of guiding principles. Retrieved May 2, 2009, from www.reading.org/General/Publications/ReadingToday/ RTY-0902-rti.aspx

Kavale, K.A., Kauffman, J.M., Bachmeier, R.J., \& LeFever, G.B. (2008). Response-to-intervention: Separating the rhetoric of self-congratulation from the reality of specific learning disability identification. Learning Disability Quarterly, 31(3), 135-150.

Kress, G.R., \& Van Leeuwen, T. (2001). Multimodal discourse: The modes and media of contemporary communication. New York: Oxford University Press.

Laird, J., DeBell, M., Kienzl, G., \& Chapman, C. (2007). Dropout rates in the United States: 2005. Washington, DC: National Center for Educational Statistics.

Love, M.S. (2004). Multimodality of learning through anchored instruction. Journal of Adolescent \& Adult Literacy, 48(4), 300310. doi:10.1598/JAAL.48.4.3

McCarthey, S.J., \& Moje, E. (2002). Identity matters. Reading Research Quarterly, 37(2), 228-238. doi:10.1598/RRQ.37.2.6

McPhail, J.C., Pierson, J.M., Freeman, J.G., Goodman, J., \& Ayappa, A. (2000). The role of interest in fostering sixth grade students' identities as competent learners. Curriculum Inquiry, 30(1), 43-70. doi:10.1111/0362-6784.00153
Mraz, M., Rickelman, R.J., \& Vacca, R.T. (2009). Content-area reading: Past, present, and future. In K.D. Wood \& W.E. Blanton (Eds.), Literacy instruction for adolescents: Research-based practice (pp. 77-91). New York: Guilford.

National Education Summit on High Schools. (2005). An action agenda for improving America's high schools. Retrieved June 11, 2009, from www.achieve.org/SummitActionAgenda

New London Group. (1996). A pedagogy of multiliteracies: Designing social futures. Harvard Educational Review, 66(1), 60-92.

O'Brien, D.G., \& Bauer, E.B. (2005). New literacies and the institution of old learning. Reading Research Quarterly, 40(1), 120-131. doi:10.1598/RRQ.40.1.7

O’Brien, D.G., Stewart, R., \& Moje, E. (1995). Why content literacy is difficult to infuse into the secondary school: Complexities of curriculum, pedagogy, and school culture. Reading Research Quarterly, 30(3), 442-463. doi:10.2307/747625

Organisation for Economic Co-Operation and Development. (2001). Knowledge and skills for life: First results from PISA 2000. Paris: Author.

Pajares, F. (1996). Self-efficacy beliefs in academic settings. Review of Educational Research, 66(4), 543-578.

Phelps, L.A., \& Hanley-Maxwell, C. (1997). School-to-work transitions for youth with disabilities: A review of outcomes and practices. Review of Educational Research, 67(2), 197-226.

Rampey, B.D., Dion, G.S., \& Donahue, P.L. (2009). The nation's report card: Trends in academic progress in reading and mathematics 2008. Retrieved June 11, 2009, from nces.ed.gov/nations reportcard/pubs/main2008/2009479.asp

Schofield, A., \& Rogers, T. (2004). At play in fields of ideas. Journal of Adolescent \& Adult Literacy, 48(3), 238-248. doi:10.1598/JAAL.48.3.5

Shanklin, N.E. (2008). At the crossroads: A classroom teacher's key role in RTI. Voices From the Middle, 16(2), 62-63.

Street, B.V. (2003). What's "new" in new literacy studies? Critical approaches to literacy in theory and practice. Current Issues in Contemporary Education, 5(2), 1-14.

Sturtevant, E.G., Boyd, F.B., Brozo, W.G., Hinchman, K.A., Moore, D.W., \& Alvermann, D.E. (2006). Principled practices for adolescent literacy. A framework for instruction and policy. Mahwah, NJ: Erlbaum.

U.S. Department of Education. (2004). Building the legacy: IDEA 2004. Washington, DC: Author. Retrieved June 21, 2007, from idea.ed.gov/explore/view/p/\%2Croot $\% 2$ Cregs $\%$ 2C300\%2CD\%2C300\%252E307\%2C

Brozo teaches at George Mason University, Fairfax, Virginia, USA; e-mailwbrozo@gmu.edu. 